\title{
Explicit Grammar and Implicit Grammar Teaching for English Major Students in University
}

\author{
ZHENG Ling \\ Changchun University, Changchun, China
}

\begin{abstract}
The status of English grammar teaching in English teaching has weakened and even once disappeared in part English class; until the late 1980s, foreign English teachers had a consistent view of the importance of grammar teaching. In recent years, more and more domestic scholars begin to think about the situation of China and explore the grammar teaching method. This article will review the explicit grammar instruction and implicit grammar teaching research, collect and analyze the integration of explicit grammar instruction and implicit grammar teaching strategy and its advantages in the grammar teaching.
\end{abstract}

Keywords: grammar teaching, explicit grammar teaching, implicit grammar teaching

\section{Introduction}

In the field of English teaching, grammar teaching has always been a controversial topic. In the 1960s, due to the popularity of the grammar translation method, grammar is quite seriously. In recent years, more and more domestic scholars begin to explore the grammar teaching method that are suitable for the situation of China and think about the status of grammar teaching in college English teaching and the best combining site of language teaching theory with practice. This article basically introduces the theoretical basis, analyzes the Explicit Grammar Instruction and Implicit Grammar Teaching, in order to provide reference for the related research.

\section{Theoretical Basis}

\section{Explicit Learning and Implicit Learning}

The concept of "explicit learning" and "implicit learning" was firstly proposed on the basis of finite state grammar experiment in 1967. "Explicit learning" refers to learning the vocabulary and grammar in language materials by dominant means, such as memory, grammar analysis, and so on, which is a process conscious and controlled. In this process, the learners know the composition of the learning process and can fully express the knowledge that has learned. By contrast, "implicit learning" is a kind of unconscious behavior, namely the learners do not know the content they are learning in the process of learning, also do not know who is learning, which can not be built and verified. Explicit learning has the characteristics of purpose, consciously, controllability and learning. While implicit learning is automatic, abstract, stable, and anti- interference.

ZHENG Ling, lecturer, master, Foreign Languages College, Changchun University. 


\section{Explicit Knowledge and Tacit Knowledge}

Explicit knowledge is the components of a language about learners and the role language knowledge plays in human life. In a nutshell, explicit knowledge is declarative knowledge about language and language use. People can learn the explicit knowledge from the definition put forward by Krashen (1982, pp. 58-59), explicit knowledge is the knowledge learned by people consciously, and it can be expressed by language. While tacit knowledge is knowledge that learners know completely unconscious, namely the learners do not know the knowledge.

DAI Man-chun (2005) defined tacit knowledge acquisition as occasional, recessive knowledge storage, and automatic use (pp. 31-41). When children learn mother tongue, they master the characteristics and rules of mother tongue in an unconscious state. The knowledge that they acquire is called recessive knowledge.

\section{The Study of Explicit Grammar Instruction and Implicit Grammar Teaching}

\section{The Meaning of Implicit Grammar and Explicit Grammar Teaching}

Explicit grammar teaching. Explicit grammar teaching refers to the teaching methods making form as the center, it emphasizes to learn the grammatical rules purposeful, so as to efficiently and accurately use language ingredient. Which is also called "express method", known as the main thinking method of deduction. Explicit grammar teaching is a main method in the traditional grammar teaching, represented by grammar - translation method. Explicit grammar teaching, which achieve the objective of the master grammar by studying grammar rules, emphasize the awareness purpose and controllability in the process of learning grammar.

Explicit grammar teaching can make students more profoundly understand the grammatical items, and it has strong systemic. Besides, students will keep clear when studying the grammar concepts. Chinese students are lack of required language learning environment when learning English, so they must master grammar rules. However, there exist some problems in the dominant teaching method, such as the teacher does not pay attention to the practical application of language, which is not conducive to cultivate the students' communicative competence in an all-round way. Besides, since learners is very strong to learn the meaning of language in certain situations, students will not be interested in and cause attention inevitably when teacher teach grammar rules simply in the grammar teaching.

Implicit grammar teaching. Implicit grammar teaching refers to the teaching methods emphasizing students must be naturally acquired through situational scene when learning grammar. Implicit grammar teaching is also known as suggestive method, mainly adopting the inductive thinking method, and inducing the grammar rules through communicative use of the language. Learners contact with English mainly through scenes. This teaching method makes communicative teaching method as representation, emphasizing the unconsciousness, abstractness, and automaticity of grammar study.

Explicit grammar teaching, which makes teachers as the center in classroom teaching, is too fancy language and forms the teaching mode whose center is grammar activity. With this teaching method, most of the students can make grammatical and correct sentences, but cannot use English for simple daily communication. For this, it requires teachers to combine the language form with language meaning and language function organically. Implicit grammar teaching can let learners gain a better understanding of the relationship between the semantics and function and context by incorporating the discourse into the context. 


\section{Research on the Grammar Teaching}

Study shows that the understanding of grammar knowledge can promote the process of language acquisition, and the best way of teaching is the combination of the dominant and recessive teaching. It is not hard to see from the above analysis that the implicit grammar teaching way can provide more interaction between teachers and students; the classroom atmosphere will also be more active relative to the explicit teaching. Therefore, both implicit grammar teaching and explicit grammar teaching have advantages and disadvantages, but the two are not contradictory. Teachers should combine the implicit grammar teaching with the explicit grammar teaching explicitly in teaching practice in the light of the actual situation of students and the teaching reality of environment and conditions.

\section{Combination of Implicit Grammar and Explicit Grammar Teaching}

College English classroom should develop the students' ability of practical application, namely how to improve students' listening, speaking, reading, writing, and translating ability. The grammar teaching in college classroom is explained and force-feeding. In class, the teacher wants to tease out each important grammar rules of the project, and lists a large number of examples, so as to cope with the exam; students have to bite the bullet and take notes. Such teaching method is too drab and inflexible, which is unable to help the students master the English language at the core of the project and improve students' ability to use English grammar. Such teaching method excessively emphasizes the instrumental of language, thus, English class becomes a language skills classes. Therefore, the teacher should deal with the relationship between the dominant teaching and recessive teaching in teaching grammar.

\section{Application of Multimedia Teaching}

Application of multi-media equipment in the process of grammar teaching, can import the real context of teaching resources with simulating, such as integrating sound, images, text, and animation.

The multimedia English teaching based on modern education technology is changing the traditional mode of classroom teaching. English teaching has brought a new breath. China's college students learn English lack of natural language environment and cultural environment; In the classroom, the teacher should spend all the time and space in developing simulated and virtual language environment so that the students will be exposed and improve the efficiency of English learning.

When teachers are teaching grammar, they can properly use the functions of multimedia, such as sound, figure, demonstration, and playback. Thus, explaining the language difficulty and emphasis of the text, and organizing students to participate in the activities of all kinds of language practice and language use, language input and output. After the interpretation of the text, teacher should design related language output activities, like presentation, discussion, role playing, and others, so as to help students digest the content they have learned timely, and strengthen the sensibility of grammar and English thinking ability. The use of multimedia can change the boring and static grammar interesting, which will mobilize the students' enthusiasm and initiative of learning.

When teaching of the usage of subjunctive mood in the virtual condition of adverbial clauses, teachers can use multimedia to product PPT and explain in detail in this illustrated way. For example, teachers can try to design the scenario of "If I were a bird, I would fly into the sky". By doing this, not only can it cause student's interest, but also explain the change of the predicate verb more intuitive in the subjunctive mood. Besides, 
students can consolidate the grammar points in the simulation context, such as "If I were the astronaut, I would. / If I were the CEO (Chief Executive Officer), I would".

Explicit grammar teaching emphasizes the students' attention to the language form, while implicit grammar teaching emphasizes the meaning centered. The application of multimedia in college English grammar teaching enables the student to create real language context, and helps them combine the language form with the meaning well through a lot of collaborative and interactive.

\section{Teaching Using English Newspapers and Magazines}

News English language is true and mainstream, is also the most real, practical, and modern carrier reflecting the newest development of the English language. English newspaper is one of the medium of English news articles. English newspapers and periodicals embody the application of grammatical rules in real context. Therefore, introducing English papers to college English grammar teaching, the language no longer taught in isolation, and extending the scope of the discourse grammar teaching will increase the chances of students contacting English, and stimulate students interest and motivation to learn grammar.

For example, when teaching the passive voice, teachers should make the students know the basic structure of passive wooden, as well as the function and significance of the passive voice. First of all, the passive voice emphasizes the object of action, because of its action practitioners are often unknown or unimportant, so you often omit. Secondly, the passive voice is used to express formally and objectively avoiding subjective impression on the person. Again, the passive voice is tactful avoiding mentioning senders action; a large number of titles in English newspapers and magazines are good materials to learn the passive voice.

Besides, apart from the perspective of the news headlines, the teacher can also choose the appropriate news discourse, and design appropriate activities, so as to strengthen students' understanding of the passive relevant usage.

\section{Conclusion}

To sum up, the dominant grammar improves the students' attention to language form, and causes the student to remember the grammar project through a lot of sentence pattern training. However, explicit grammar teaching pays too much attention to language forms, which makes that most students can make sentences grammatically accurate, but can not communicate with simple English. Implicit grammar teaching classroom atmosphere is relatively active, which can provide more interaction between teachers and students through the interactive feedback, thus the output of students is more efficient and accurate. Implicit grammar teaching emphasizes more on grammar functions, while explicit teaching method increases the perceptual knowledge to rational knowledge. The two kinds of teaching methods have no quality; people can reasonably choose the two kinds of teaching methods and make a full use of explicit grammar teaching and implicit grammar teaching. Explicit grammar teaching and implicit grammar teaching are not mutually exclusive two opposites, but complement each other, and are two parallel methods of teaching English suitable for different materials, objects, situation, and stage.

\section{References}

Başöz, T. (2014). Through the eyes of prospective teachers of English: Explicit or Implicit grammar instruction? Procedia—Social and Behavioral Sciences, 12(103).

Burgess, J., \& Etherington, S. (2002). Focus on grammatical form: Explicit or implicit? System, 30(4), 433-458. 
CAI, X. F. (2005). Interactive principle and college English multimedia network teaching model research. Journal of Xi'an Foreign Languages Institute, 26(8), 73.

DAI, M. C. (2005). The dominant and recessive problems of second language acquisition. A Foreign Language and Literature (Quarterly), 34 (5), 31-41.

HAO, X. Y., \& YIN, Z. P. (2005). Research on the explicit grammar and lmplicit grammar teaching. Journal of Yunnan Normal University, 17(8), 119-123.

Krashen, S. (1982). Principles and practice in second language acquisition (pp. 58-59). Oxford: Pergamon.

Potgieter, A. P., \& Conradie, S. (2013). Explicit grammar teaching in EAL classrooms: Suggestions from isiXhosa speakers' L2 data. Southern African Linguistics and Applied Language Studies, 31(1), 111-127.

Spada, N. (2009). Form-focused instruction in second language acquisition: A review of classroom and laboratory research. Language Teaching, 30(2), 29. 